rica and America. The main divisions are books and pamphlets, which is followed by a broad topical subject index, with subheadings such as "Protest and Rebellion" and "The Negro in Arms" and includes a few cross-references. Two additional sections treat manuscripts and broadsides separately, although neither section is indexed. Within sections, entries are numbered consecutively in an alphabetical sequence and consist of author, title, place of publication, publisher, date of publication, and pagination. Physical location of books transferred to the Library Company from the Historical Society use the designation (HSP in LCP), while Library Company manuscripts, all of which were transferred to the Historical Society, are denoted (LCP in HSP).

The long-awaited second edition of Afro-Americana 1553-1906 reprints the 16,000 entries of the first edition and appends an additional 2,500 printed works, preceded by a brief introduction, in a supplement at the end of the catalog. The printed works, with the exception of manuscripts, which are not represented in the second edition, consist of books, pamphlets, and broadsides added to the Library Company under Phillip Lapsansky, Curator of Afro-Americana, since the publication of the first edition. Entries are numbered consecutively and alphabetized. The majority of titles are published between 1553 and 1906, with some important later items listed; a good example is Booker T. Washington's The Story of the Negro: The Rise from Slavery, published in 1909 [suppl. no. 2450].

Additions made to the Historical Society since 1973 are not represented in the supplement. However, users are advised to consult the prologue to the second edition for a description of the Historical Society's efforts to augment existing holdings of African Americana by way of merger with the Balch Institute for Ethnic Studies in 2002. Other ongoing efforts include acquisition of post-1900 collections, the introduction of online finding aids to enhance access to manuscript collections, the creation of topical research guides available on the Web, and digitization of Underground Railroad documents.

The second edition also reprints the original introduction and prologue prepared by the Library Company and the Historical Society for the first edition. No corrections, revisions, or changes are made to the first edition entries; and, unfortunately, no index exists for the newly added supplement. Still, the catalog will interest specialists in the field and is suitable for large research libraries. - Emily M. Belcher, Princeton University.

1. Philadelphia. Library Company. Negro History, 1553-1903: An Exhibition of Books, Prints, and Manuscripts from the Shelves of the Library Company of Philadelphia and The Historical Society of Pennsylvania, 1300-14 Locust Street, April 17 to July 17, 1969. Philadelphia, 1969.

2. Afro-Americana 1553-1906: Author Cata$\log$ of the Library Company of Philadelphia and the Historical Society of Pennsylvania. 2nd ed. New Castle, Del.: Oak Knoll Press, 2008.

\section{Case Studies in Library and Information}

Science Ethics. Eds. Elizabeth A. Buchanan and Kathrine A. Henderson. Jefferson, N.C.: McFarland \& Co., 2009. 165p. alk. paper, $\$ 49.95$ (ISBN 9780786433674). LC2009-034606.

"Nothing is more important than the way we treat each other," writes Robert Hauptman in the foreword to this slim yet useful volume of case studies in professional ethics. Although the text is peppered with more and less opaque explorations of what ethics mean - moving from Plato to Heidegger to a particularly dense discussion of intercultural ethics by Rafael Capurro-the essential questions boil down to this quite simple formulation by Hauptman: What does the call to be good to each other mean for libraries? Buchanan and Henderson encourage readers to grapple critically with this question through an exploration of five general themes relevant to librarians: intellectual freedom, privacy, intellectual property, professional ethics, and inter- 
cultural information ethics. Each section begins with a contextualizing discussion of the particular issue, followed by a brief bibliography and a series of cases with questions to consider for discussion.

This volume is meant as both a classroom and a staffroom text. Buchanan and Henderson give both historical and contemporary context to their discussions of each issue, and this framing of ethical debate will prove particularly useful to LIS students. For example, the chapter concerning intellectual freedom discusses both historical approaches taken by professional associations in the United States and Canada as well as some of the more common contemporary measures, including the PATRIOT Act, the Digital Millennium Copyright Act, and efforts to make Internet filtering mandatory in public libraries. Those working in libraries will already be familiar with many of these debates, but the clear and concise explanations will serve as quick and thorough refreshers to those of us whose daily labor threatens to overwhelm our ability to think critically about the values that guide our actions. Each issue discussion is followed by 25 case studies that use imaginary situations to prompt concrete discussion of abstract ethical principles. The case studies, real strengths of the book, engage different angles or approach inherent ethical questions, demonstrating the enormous range of real-life situations that require professional librarians to grapple with ethical principles. Cases are set in public, special, and academic library settings, and many will be instantly recognizable to practitioners: the student photocopying reserve materials one chapter at a time, in potential violation of copyright; the suspiciously hovering older man in the children's room whose right to privacy must be balanced with safety concerns; the demand by a faculty member to know who has checked out the video he needs for class right this very second. For many of us, these situations are so common that we may not even consider the need to engage in debate about our responses. Buchanan and Henderson's collection is both a cogent reminder and a practical workbook for taking up this professional demand anew.

Most of this book is written by Buchanan and Henderson, but they oddly chose to reprint a chapter on the emergent field of intercultural information ethics by Rafael Capurro, a German LIS theorist. His chapter on intercultural information ethics presumes a working knowledge of debates in contemporary East-West philosophy and is written in a dense prose style that will be unfamiliar to most library professionals. Capurro's focus could not be more important or more relevant. He asks us to consider what professional ethics mean in an increasingly globalized and globally connected world. For example, how does the U.S. professional commitment to intellectual property square with competing cultural commitments in China to free flow of information? Capurro invites us to engage in a conversation about our ethics that acknowledges cultural differences and encourages the formulation of a new kind of ethics produced through intercultural dialogue. It's a worthy call, but one that is difficult to heed when it is this difficult to understand. The reader wishes Buchanan and Henderson had taken up the task of translating this highly theoretical language into the clear and direct approach that makes the rest of this volume such a compelling addition to our educational and professional collections. - Emily Drabinski, Long Island University, Brooklyn Campus.

Kelty, Christopher M. Two Bits: The Cultural Significance of Free Software. Durham, N.C.: Duke University Press, 2008. 378p. alk. paper, $\$ 23.95$ (ISBN 978-0-8223-4264-9). LC 2007-049447.

Little did Christopher M. Kelty, an assistant professor of anthropology at Rice University in Houston, Texas, expect to become an active member in the culture he set out to investigate - that of Free Software, or Open Source software. 